\title{
ANALISIS VARIASI INCLUDED ANGLE TERHADAP DISTORSI PADA SAMBUNGAN LAS SMAW
}

\author{
Prihatno Kusdiyarto $^{1}$, Riswan Dwi Djatmiko ${ }^{2}$ \\ 1, 2 Jurusan Pendidikan Teknik Mesin, Universitas Negeri Yogyakarta \\ Email: prihatnokusdiyarto@uny.ac.id
}

\begin{abstract}
The aim of this study is to determine the effects of included angle dimenison on the distortion of carbon steel V-groove butt joint using a single pass welding methods. Specimens being studied were AISI 1025 low carbon steel in the form of 1/2 inch-thick plates. The steels were easily weld and were assumed as homogeneous and isotropic; therefore, three specimens for each treatment are adequate. The experiment treated the v-groove shape as independent variable and the distortion as dependent variable. The results show that there is an effect of vgroove dimensions on the distortion of the carbon steels butt joint.. The distortion and their respective angle dimensions are $0.58^{\circ}$ for the $55^{\circ}$ angle, $0.78^{\circ}$ for the $60^{\circ}$ angle, and $1.02^{\circ}$ for the $65^{\circ}$ angle. The magnitude of the distortions are well below $3^{\circ}$, which is the permissible amount for the butt joint distortion criteria.
\end{abstract}

Keywords: included angle, distortion, SMAW

\begin{abstract}
ABSTRAK
Tujuan penelitian ini untuk mengetahui ada tidaknya pengaruh dimensi included angle (bentuk kampuh) terhadap distorsi pada sambungan ujung baja karbon dengan metode pengelasan SMAW single pass. Dalam penelitian ini obyek yang diteliti adalah baja karbon rendah type AISI 1025 yang berupa plat strip dengan ketebalan $1 / 2$ inchi. Baja jenis ini merupakan bahan yang mudah dilas dan diasumsikan homogen dan isotropic, sehingga sampel yang diambil cukup tiga buah pada masing-masing perlakuan. Bentuk included angle merupakan variabel bebas dan distorsi adalah variabel terikat. Hasil penelitian menunjukkan adanya pengaruh dimensi included angle terhadap distorsi pada sambungan ujung baja karbon. Besarnya distorsi pada sambungan dengan dimensi sudut $55^{\circ}$ sebesar $0,58^{\circ}, 60^{\circ}$ sebesar $0,78^{\circ}, 65^{\circ}$ sebesar $1,02^{\circ}$. Hal ini memberikan informasi bahwa variasi sudut included angle tersebut menghasilkan distorsi di bawah $3^{\circ}$, sehingga masih termasuk dalam batas yang diijinkan persyaratan kelolosan sambungan las.
\end{abstract}

Kata kunci: included angle, distorsi, SMAW

\section{PENDAHULUAN}

Sambungan las adalah ikatan dua buah logam atau lebih yang terjadi karena adanya proses fusi akibat pemanasan atau tekanan yang membuat kedua logam tersebut menyatu menjadi sambungan permanen. Proses penyatuan dalam sambungan las dapat dilakukan dengan kondisi padat maupun cair. Pengelasan merupakan metode untuk penyambungan logam dengan menyatukan ujung dari logam yang disambung secara metalurgi. Proses penyatuan dalam sambungan las dapat dilakukan dengan kondisi padat maupun cair. Dalam terminologi las, kondisi padat disebut solid state welding (SSW) atau presure welding dan kondisi cair disebut liquid state welding (LSW) atau fusion welding.

Las busur listrik atau yang lebih dikenal dengan sebutan SMAW (Shielded Metal Arc Welding) merupakan salah satu jenis las yang tergolong LSW dimana logam yang dilas harus dipanasi sampai mencair. Pemanasan logam dengan temperatur yang sangat tinggi ini dapat mengakibatkan terjadinya reaksi kimia antara logam tersebut dengan oksigen dan nitrogen yang ada dalam udara. Jika selama proses pengelasan cairan logam las tidak dilindungi dari pengaruh udara, maka logam las akan bereaksi dengan oksigen dan nitrogen 
membentuk oxides dan nitrides. Oxides dan nitrides dapat menyebabkan logam tersebut menjadi getas dan keropos karena adanya kotoran (slag inclutions), sedangkan kandungan unsur karbon dalam logam akan membentuk gas CO yang dapat mengakibatkan adanya rongga dalam logam las (caviety).

Selain hal di atas dan karena proses pengelasan melibatkan pemanasan benda kerja hingga terjadi pencairan, dipastikan benda kerja menerima masukan panas yang melebihi batas temperatur rekristalisasinya. Selanjutnya, benda mengalami pendinginan yang cukup cepat. Masukan panas yang tinggi dan pendinginan yang cepat ini menyebabkan terjadinya ekspansi pada bahan yang dilas. Proses ekspansi tersebut menyebabkan adanya distorsi.

Distorsi terdiri dari longitudinal, transversal, dan angular. Distorsi longitudinal terjadi perubahan bentuk pada sepanjang garis pengelasan. Distorsi transversal terjadi pada garis melintang sumbuh pengelasan, sedangkan distorsi angular menyebabkan benda kerja berubah bentuk ke arah menyudut. Distorsi merupakan cacat yang sulit dihindari jika prosedur pengelasan tidak dirancang dengan benar. Ada beberapa hal yang dapat mencegah terjadinya distorsi pada sambungan las, diantaranya adalah 1) pengikatan (tack weld) bagian yang disambung, 2) pemilihan bentuk kampuh yang tepat sesuai ketebalan benda kerja, 3) teknik weaving, 4) heat input disesuaikan dengan ketebalan benda kerja, dan 5) penerapan pengelasan intermiten pada sambungan las yang panjang.

Kendatipun sudah diketahui beberapa variabel yang mempengaruhi terjadinya distorsi, tetapi masih belum bisa diketahui secara akurat besaran variabel tersebut, oleh karenanya pencegahan distorsi masih tergantung dari pengalaman seorang welder. Bagi welder pemula atau yang belum memiliki pengalaman pencegahan distorsi sebagaimana mahasiswa yang masih dalam taraf belajar, tentunya sangat kesulitan melakukan pengelasan tanpa terjadi distorsi karena belum adanya ukuran variabel yang mempengaruhi terjadinya distorsi pada sambungan las.

Berkaitan dengan kesulitan pencegahan distorsi dalam proses las, perlu ada penelitian yang mengungkapkan ukuran variabel yang mempengaruhi distorsi, sehingga pencegahan distorsi pada sambungan las dapat dieliminasi dengan baik. Hasil penelitian ini tidak hanya dapat diterapkan dalam proses pengelasan di industri saja, tetapi juga sebagai penerapan ilmu pengelasan yang bisa dijadikan acuan dalam membuat prosedur pengelasan dan rujukan bagi siapa saja yang berkepentingan dengan pengelasan logam.

Saat ini teknik pengelasan masih banyak yang menggunakan panas untuk mencairkan bahan yang akan disambung. Beberapa sumber panas untuk keperluan pencairan bahan diantaranya adalah busur listrik, reaksi termal, tahanan litrik, dan lainnya. Penggunaan panas dan pendinginan cepat ini menyebabkan terjadinya distorsi pada sambungan las. Toyoda (2008) menjelaskan bahwa heating and subsecuent colling localized only near the welded joint cause welding residual stress and welding distortion.

Distorsi akan menyebabkan dimensi sambungan las tidak sesuai dengan dengan desain yang dibuat, bahkan jika distorsi ini melebihi batas penerimaan standar yang telah ditentukan, maka sambungan las harus diperbaiki. Hal ini tentu merupakan kerugian perusahaan, karena perbaikan membutuhkan biaya tambahan dan menambah waktu penyelesaian pekerjaan, oleh karenanya distorsi tersebut perlu dieliminasi.

Penyebab utama terjadinya distorsi adalah prosedur pengelasan yang tidak sesuai dengan dimensi dan properti bahan yang dilas. Dari prosedur pengelasan yang tidak benar ini, parameter laslah yang paling banyak berkontribusi terhadap terjadinya distorsi. Parameter las menyebabkan ketidaksesuaian masukan panas yang diterima oleh bahan yang dilas. 
Toyoda (2008) menjelaskan bahwa masukan panas di bawah $5 \times 10^{9} \mathrm{~J} / \mathrm{m}^{3}$ sedikit pengaruhnya terhadap distorsi, tetapi jika di atas $5 \times 10^{9} \mathrm{~J} / \mathrm{m}^{3}$ sampai dengan $15 \times 10^{9} \mathrm{~J} / \mathrm{m}^{3}$ sangat berpengaruh terhadap distorsi, dan di atasnya kembali lagi sedikit pengaruhnya terhadap distorsi tersebut. Gambaran lebih lengkap bisa dilihat pada Gambar 1.

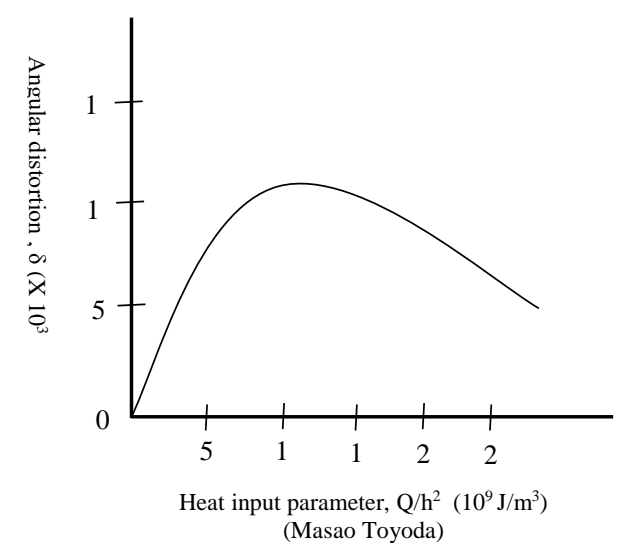

Gambar 1. Pengaruh masukan panas terhadap distorsi

Ada beberapa jenis variabel yang mempengaruhi besar kecilnya masukan panas, yaitu: 1) arus las, 2) tegangan las, 3) arc length, dan 4) kecepatan las. Arus dan tegangan las berkaitan langsung dengan ketebalan benda kerja dan diameter elektroda. Arc length tergantung dari jenis elektroda yang digunakan untuk pengelasan. Kecepatan las sangat tergantung pada bentuk alur/kampuh las dan teknik weaving welder ketika melakukan pengelasan, karena kedua variable tersebut berhubungan dengan banyaknya volume bahan tambah/elektroda yang dideposisikan pada kampuh las. Semakin banyak volume yang dideposisikan pada sambungan las semakin besar pula kemungkinan terjadi distorsi.

American Welding Sociaty (AWS) (2000: 51) memberikan batasan bahwa rigid fixtures and careful selection of welding sequence, welding processes, and joint design can minimize this condition. Di sini jelas bahwa penggunaan fixture, penentuan urutan pengelasan (teknik weaving), desain proses, dan desain sambungan las dapat meminimalisir terjadinya distorsi.

Penentuan teknik weaving dapat menyebabkan keseimbangan tegangan pada sambungan las dan dapat mengurangi terjadinya distorsi, demikian juga dengan desain sambungan las, karena dengan desain ini kita bisa merencanakan ukuran root face, root gap, dan included angle yang dapat mengoptimalkan volume deposit logam las yang tepat sehingga dapat mengeliminasi terjadinya distorsi.

Pengelasan alur umumnya dibuat dalam bentuk butt joint (sambungan ujung) dari 1,2 $\mathrm{mm}(0,05$ inch) logam tipis sampai logam yang tebal. Penetrasi terbesar masuk dalam SAW (submerged arc welding) dibuat dengan sudut alur persegi sebesar 1/2 inch atau lebih dalam ketebalan pengelasan sempurna dari satu sisi, disediakan beberapa bentuk yang digunakan untuk logam jenis molten. Pengelasan single pass di atas 5/16 inch dan pengelasan two pass di atas 5/8 inch tebal baja dibuat sebuah alur persegi groove posisi butt joint, tidak ada root yang terbuka, dan pengelasan sampai akhir.

Dengan pengelasan multiple pass, menggunakan elektrode single atau multiple, plat dengan tebal 1,5 sampai 24 inch) yang dapat dilas. Pengelasan dengan material tebal, ketika deposit dari kedua sisi dapat diukur kampuh $\mathrm{V}$ atau $\mathrm{U}$ pada satu atau dua sisi pada plat.

Bentuk dari pengelesan alur pada sambungan butt joint pada posisi horisontal dapat diketahui dari posisi pengelasan jam 3 dari analogi posisi jam. Pengelasan jenis ini dapat dibuat dari kedua sisi pada simulasi sambungan. Pada kebanyakan kasus, elektroda diposisikan pada sudut 10 sampai 30 derajat di bawah posisi horisontal. Flux untuk mendukung pengelasan dan logam molten, beberapa dari pergeseran/pergerakan las digunakan. 


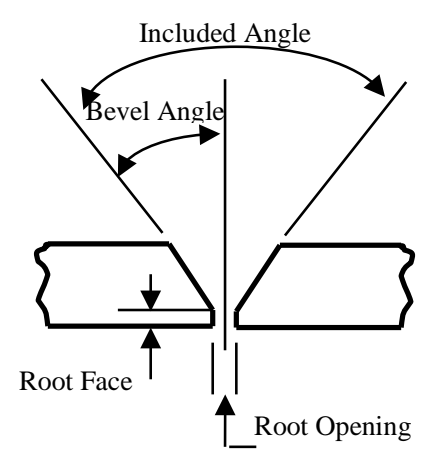

Gambar 2. Weld Joint Difinitions

Dalam literatur training in basic SMAW dari Hobart School (1980: 101) dijelaskan tentang ukuran standar: included angle $70^{\circ}$, bevel angle $35^{\circ}$, root face $1 / 16$ " dan root opering $1 / 16$ ” sampai 3/32".

Penelitian terkait distorsi ataupun included angle sudut $\mathrm{V}$ groove diantaranya diteliti oleh Yanhong Ye (2015), menyebutkan bahwa distorsi sudut sendi butt secara signifikan dipengaruhi oleh jenis groove, tekanan residu pengelasan dan distorsi sudut pada sendi V-groove yang diprediksi oleh model elemen hingga sesuai dengan data yang terukur sudah terbukti. Tegangan tarik longitudinal pada sendi V-groove sedikit lebih lebar dibanding dengan K-groove atau $\mathrm{X}$ groove joint, dan Dari sudut pandang pencegahan SCC pada sambungan butt joint pada baja austenitik yang dilas bersama, hasil simulasi menunjukkan bahwa X-groove dan Kgroove lebih unggul dari V-groove. Pankaj Biswas (2010) menjelaskan dalam hasil penelitiannya bahwa pengelasan busur (GTAW pada root pass dilanjutkan SMAW pada filler running) pada celah sempit V-groove pada material jenis SS316LN, karena masukan panas dan volume pengelasannya rendah, ia mengurangi tekanan termal yang menyebabkan pengurangan tegangan sisa dan distorsi. Pada pengelasan ini didapatkan distortion sectional yang disebabkan oleh pengelasan ditemukan adanya variasi distorsi dari 0,7 sampai $0,3 \%$ dengan mengabaikan penjepitan clam selama pengelasan.

Junhao Sun (2016) meneliti tentang sambungan butt joint antara paduan aluminium
AA6061 dan baja karbon rendah Q235 dengan ketebalan 2,5 $\mathrm{mm}$ dilakukan dengan menggunakan metode pengelasan las laser dengan logam pengisi ER4043. Proses galvanisasi baja dilakukan untuk mendapatkan lapisan seng pada permukaan baja sebelum pengelasan. Hasil penelitian menunjukkan bahwa sambungan suara antara $\mathrm{Al}$ dan baja diperoleh, dengan antara brazing terdiri dari daerah kaya seng dan lapisan intermetalik Fe-Al (IMC). Morfologi lapisan reaksi IMC lebih kompleks dan lapisannya lebih tebal saat included angle baja yang lebih kecil digunakan. Semua sendi retak di lapisan Fe2Al5 dari antarmuka mematri. Kekuatan tarik sendi itu terutama ditentukan oleh daerah ikatan antarmuka brazing, dan kekuatan tarik rata rata 110 MPa dan150 MPa dicapai bila included angle masing-masing $45^{\circ}$ dan $30^{\circ}$.

$$
\text { Mohd Shahar Sulaiman }
$$

menjelaskan dalam penelitiannya dengan menganalisis menggunakan data numerik elastis linier untuk memprediksi distorsi pengelasan GMAW yang terjadi, dikarenakan proses distorsi dianggap sebagai batu sandungan utama yang dapat mempengaruhi keakuratan dimensi dan dengan demikian menyebabkan untuk pekerjaan perbaikan material yang mahal. Dalam penelitiannya, deformasi pengelasan disimulasikan dengan menggunakan software FEM yang baru Weld Planner yang dikembangkan oleh ESI Group. Pengelasan baru ini digunakan untuk memprediksi distorsi pengelasan yang diinduksi pada butt dan T-joint dengan ketebalan $4 \mathrm{~mm}$. Bahan baja karbon rendah yang digunakan untuk simulasi dan studi eksperimental. Serangkaian eksperimen menggunakan proses pengelasan otomatis sepenuhnya dilakukan untuk tujuan verifikasi untuk mengukur distorsi. Dengan membandingkan antara hasil simulasi dan eksperimen, diketahui bahwa kode program ini menawarkan waktu analisis solusi yang cepat dalam memperkirakan distorsi yang diinduksi las dengan akurasi yang dapat diterima. 
Berdasarkan kajian teoritik dan kerangka pikir di atas, penelitian ini mempelajari fenomena pengaruh bentuk kampuh terhadap distorsi. Dengan mempelajari fenomena tersebut, diharapkan diperoleh bentuk kampuh yang tepat sehingga dapat mengeliminasi terjadinya distorsi pada sambungan las. Hasil penelitian ini dapat dimanfaatkan dalam prosedur pengelasan yang digunakan oleh mahasiswa, dosen, dan sivitas akademika untuk kepentingan pembelajaran atau para praktisi pengelasan agar sambungan las bisa dijamin kualitasnya secara umum.

\section{METODE}

Bahan dan peralatan yang digunakan dalam penelitian ini adalah: a) baja karbon rendah dengan type AISI 1025 yang berupa plat strip dengan ketebalan 1/2 inchi, b) mesin las SMAW merk Rilon sebagaimana ditunjukkan pada Gambar 3, c) elektroda E7016 dan E2018, d) dial indikator sebagaimana ditunjukkan pada Gambar 4, e) meja rata dan e) jangka sorong

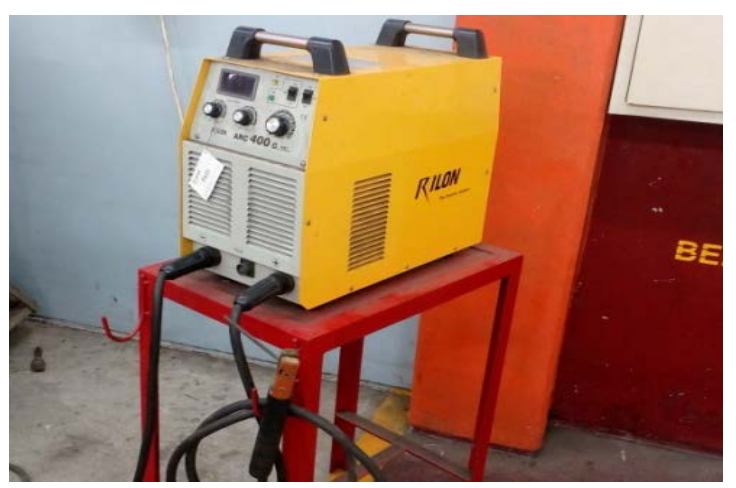

Gambar 3. Mesin Las SMAW Merk Rilon

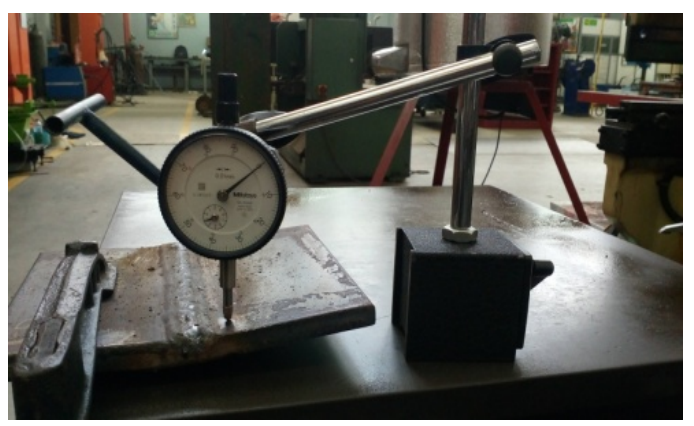

Gambar 4. Dial Indikator
Penelitian ini adalah penelitian eksperimen yang mengungkap pengaruh included angle las terhadap distorsi pada sambungan las dengan desain seperti terlihat di Tabel 1.

Tabel 1. Desain Ukuran Included Angle

\begin{tabular}{cccc} 
& IA $55^{\circ}$ & IA $60^{\circ}$ & IA 65 \\
\hline $\begin{array}{c}\text { Teknik las } \\
\text { diayun }\end{array}$ & Distorsi 1 & Distorsi 2 & $\begin{array}{c}\text { Distorsi } \\
3\end{array}$ \\
\hline
\end{tabular}

Setelah pengelasan SMAW dengan variasi bentuk kampuh $\mathrm{V}$ dilakukan, kemudian dilakukan pengambilan data, dengan menggunakan dial indikator dihitung distorsi/penyimpangan dari pengelasan. Pengukuran distorsi dilakukan baik sebelum tack weld maupun setelah pengelasan single pass. Data tersebut dianalisa terkait penyimpangannya dari posisi normal $0^{\circ}$ sambungan kampuh $\mathrm{V}$ pada baja karbon rendah dibandingkan dengan posisi setelah dilakukan pengelasan.

\section{HASIL DAN PEMBAHASAN}

Pengamatan dan pengukuran hasil las baik secara visual maupun secara pengukuran dengan menggunakan dial indikator didapatkan hasil pengelasan single pass pada material baja karbon rendah.

Setelah melakukan pengamatan visual maka didapatkan beberapa hasil pengamatan diantaranya yaitu: 1) profil sambungan las yang berupa ketinggian reinforcement, ketinggian penetrasi, kerataan bead, dan perbedaan stop start, 2) cacat dimensional yang berupa distorsi dan missalignment, 3) cacat struktural yaitu mengetahui undercut, overlap, lag of penetration, porositi, dan crack. 


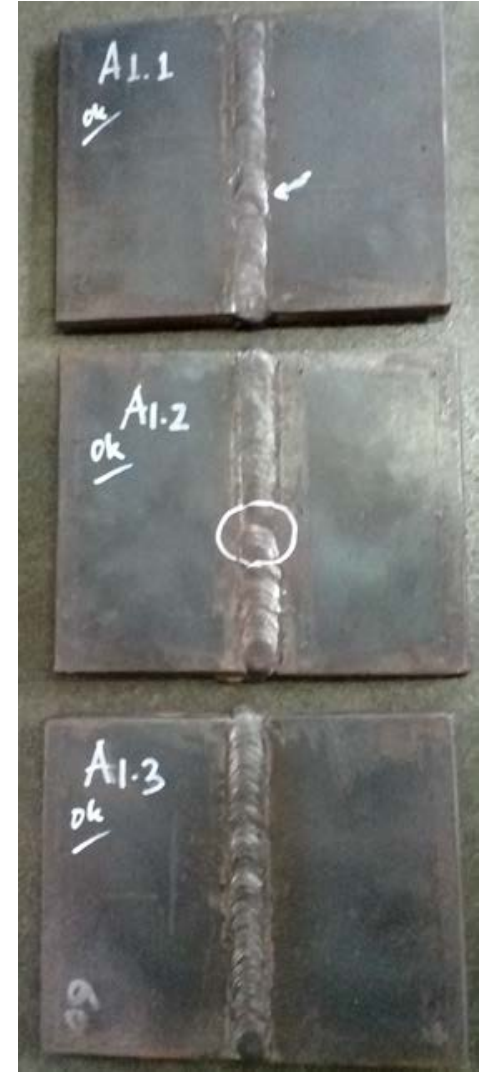

Gambar 5. Hasil pengelasan dan pengamatan visual pengelasan dengan variasi included angle

Dari pengamatan secara visual ini juga diamati tentang transversal shrinkage/ distortion. Dari beberapa jenis distortion diantaranya longitudinal shrinkage distortion yaitu penyusutan material searah atau sejajar dengan garis lurus, transverse shrinkage/ distortion yaitu penyusutan tegak lurus terhadap garis las, angular shrinkage distortion yaitu karena adanya distribusi panas yang tidak merata pada kedalaman material sehingga menyebabkan terjadinya distorsi/ perubahan sudut, rotation distortion/shrinkage yaitu distorsi sudut dalam bidang plat yang berkaitan dengan perluasaan bidang panas, buckling distortion yaitu kompresi yang bekenaan dengan panas dan menyebabkan ketidakstabilan ketika platnya tipis. Selain itu cacat las visual akan didapatkan catat las shrinkage (pengkerutan) terjadi deformasi pada material dasar setelah dilakukan proses pengelasan. Biasanya sebelum dilakukan tack weld, welder melakukan pre-bending dulu pada material yang akan dilas untuk mengurangi perubahan sudut/ distorsi hasil las agar kondisi material tetap lurus.

Setelah didapatkan data penelitian kemudian dilakukan analisis data untuk melihat distorsi yang terjadi sebelum dan sesudah pengelasan. Dari data pengukuran dapat dilihat pada Gambar 6.

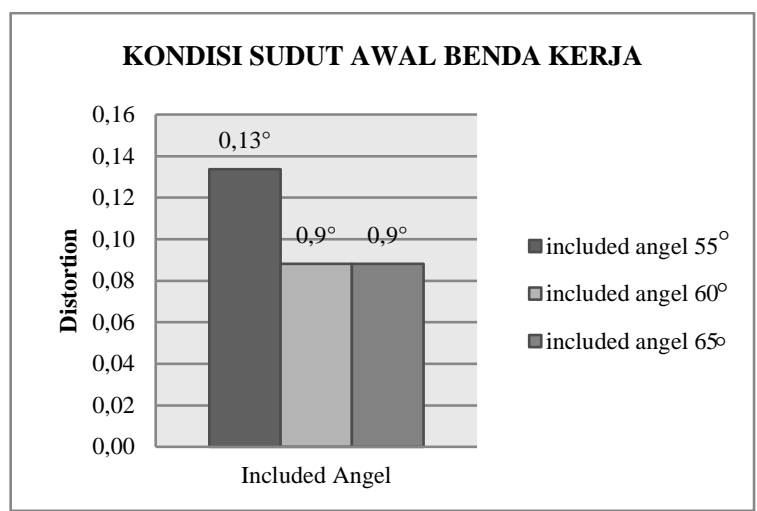

Gambar 6. Kondisi sudut awal sebelum pengelasan setelah dilakukan tack-weld

Berdasarkan Gambar 6, Kondisi sudut awal sebelum pengelasan (setelah tack weld) sebesar $0,9^{\circ}$ dan yang paling besar adalah $0,13^{\circ}$. Kondisi sudut ini akan diperhitungkan dalam penentuan distorsi.

Setelah dilakukan pengelasan, benda kerja mengalami perubahan sudut. Besar perubahan sudut setelah pengelasan ini berdasarkan hasil penelitian setiap specimen berbeda-beda bahkan jika dilihat dari dimensi kampuh juga mengalami perbedaan. Hal ini dapat dilihat pada Gambar 7.

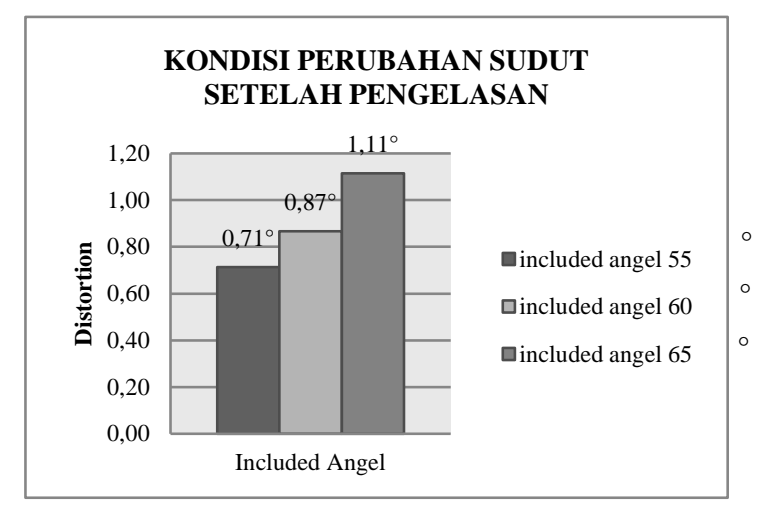

Gambar 7. Kondisi perubahan sudut setelah dilakukan pengelasan 
Gambar 7 menunjukkan adanya nilai perubahan sudut minimal sebesar $0,71^{\circ}$ dan paling tinggi adalah $1,11^{\circ}$, tetapi ini belum merupakan perubahan sudut akhir yang sebenarnya karena nilai distorsi sebenarnya tergantung pada selisih nilai perubahan sudut awal benda kerja dengan perubahan sudut setelah akhir pengelasan. Untuk mengetahui distorsi aktual benda kerja adalah dengan cara menghitung selisih perubahan sudut akhir dikurangi dengan sudut awal benda kerja yang besarnya dapat dilihat pada Gambar 6 .

Pada teknik pengelasan ini dengan diayun terlihat perubahan sudut setelah pengelasan yang terjadi paling kecil yaitu untuk included angle $55^{\circ}$ hanya sebesar $0,71^{\circ}, 60^{\circ}$ sebesar $0,87^{\circ}$, dan $65^{\circ}$ sebesar $1,11^{\circ}$. Jadi ini merupakan distorsi/selisih sudut akhir dikurangi sudut awal didapatkan sebagai berikut : untuk dimensi included angel $55^{\circ}$ sebesar $0,58^{\circ}$, included angel $60^{\circ}$ sebesar $0,78^{\circ}$, dan included angel $65^{\circ}$ sebesar $1,02^{\circ}$. Distorsi ini yang masih tergolong sempurna karena jauh di bawah $3^{\circ}$ sebagaimana persayaratan kelolosan sambungan las.

\section{SIMPULAN}

Dari analisa data dan pembahasan dapat diambil kesimpulan sebagai berikut: 1) Ada pengaruh dimensi kampuh terhadap distorsi pada sambungan ujung baja karbon, 2) Besarnya distorsi dengan teknik ayun single pass adalah untuk dimensi included angel $55^{\circ}$ sebesar $0,58^{\circ}$, included angel $60^{\circ}$ sebesar $0,78^{\circ}$, dan included angel $65^{\circ}$ sebesar $1,02^{\circ}$. Dalam hal ini distorsi yang terjadi masih tergolong sempurna karena jauh di bawah $3^{\circ}$, sebagaimana persyaratan kelolosan sambungan las.

\section{DAFTAR RUJUKAN}

AWS Committee on Methods of Inspection. (2008). Welding Inspection Handbook. Miami: The American Welding Society.

AWS. (1978). Welding Handbook Seventh Edition, Volume 2 Welding Provesses Arc and Gas Welding and Cutting, Brazing, and Soldering. Florida : American Welding Society

Biswas,Pankaj, dkk. (2010). Analysis of welding distortion due to narrow-gap welding of upper port plug. Elsevier Fusion Engineering and Design 85, 780788.

(1981). Training in basic shielded metal-arc welding a step by step explanation of the basic skills required for welding with covered electrodes. Hobart School of welding technology : Troy Ohio USA

Sulaiman, Mohd Shahar, dkk. (2011). Simulation and experimental study on distortion of butt and T-joints using Weld Planner. Springer - Journal of Mechanical Science and Technology, 25 (10) 2641-2646.

Sun, Junhao, dkk. (2016). Effect of included angle on microstructure and mechanical property

Al/steel butt joint using laser weldingbrazing method. Elsevier - Materials and Design 90, 468-477.

Toyoda, Masao. (2008). Advanced Welding and Joining Technologies. Tokyo: The Japan Engineering Society.

Ye,Yanhong, dkk. (2015). Influence of groove type on welding-induced residual stress, deformation and width of sensitization region in a SUS304 steel butt welded joint. Elsevier - Advances in Engineering Software 86, 39-48 